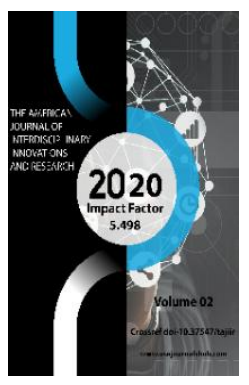

\title{
Agnonym Differences In Names
}

\author{
Kuldashev N.A \\ PhD student of Fergana State University, Uzbekistan
}

Journal Website:

http://usajournalshub.c

om/index,php/tajiir

Copyright: Original content from this work may be used under the terms of the creative commons attributes 4.0 licence.

\section{ABSTRACT}

In this article, the author emphasizes on one of the most actual issues of today is the further refinement of the purity of the Uzbek language and the prevention of distortions in the nomenclature and the correct use of words or terms. Not following the traditions of Uzbek nationality in naming will lead to some ambiguities in the language, as well as the elimination of differences in the prefixes.

\section{KEYWORDS}

Agnonym, linguocentric, anthropocentric, toponymy, linguistic source, ecolinguistics, language norm.

\section{INTRODUCTION}

The Cabinet of Ministers chaired by Prime Minister Abdullah Aripov held a video conference to discuss issues such as naming streets and settlements, the introduction of signs, advertisements and announcements in the state language on March 9, 2020. At the meeting, the Prime Minister criticized against the naming of neighborhoods, streets, enterprises and products which affects on children, contrary to the history, culture and spirituality of the Uzbek people. This shows great attention to the Uzbek language. The sultan of the realm of words, Alisher Navoi in his work "Muhokamat ul-lug'atayn" quotes the following sentences: "Tog' va tuzdagi jilg'a, suqmoq, dush, arg'adol, kirima, burtogu, 
sekritma, sirt, uchma, ishma, ilot, kiralong, to'kay, ko'l, ko'lak, oxirgi, sayang, chokil, so'y, sho'rtong kabi narsalaringni ko'targanlar" (meaning: the Persians did not name many things, such as mountain and salt valley, trail, shower, argadol, kirima, burtogu, surface, uchma, ishma, ilot, kiralong, tokay, lake, kulak, last, sayang, chokil, soy and shurtong). It is obvious that naming in Uzbek is much wider than in other languages and has an advantage in terms of vocabulary. Navoi said that Turkish, i.e. the Uzbek, is not inferior to any other language in naming.

\section{MATERIALS AND METHODS}

Today, in the period of globalization, it is becoming increasingly important to preserve the purity of our native language, preserve this priceless spiritual treasure and pass it on to future generations. It is natural that people of all nationalities are offended by the fact that the names of places, advertisements, billboards in front of buildings and structures allow indifference to our native language. Undoubtedly, these ambiguities and ambiguities in place names reduce the practical significance and prestige of the language. The term agnonym is derived from the Greek and means "unknown, incomprehensible." People who communicate in a particular language, words that are unknown, unfamiliar, incomprehensible, or incomprehensible in that language are generalized as agonyms. Agnonyms are not (linguocentric) (Mahmudov, 2018), but anthropocentric phenomena (Yuldashev, 2007). It can be taken as an event related to the ability of some language users in the society. An agonym is a lexeme that is incomprehensible to those who communicate in the same language and must meet in some form in the process of communication. Olatug'anoq (Olatug'anoq olg'ir katta bo'Isa ham, qarchaydayday bulmas)(meaning: Alatuganak (Alatuganak is not like a lizard, even if it is heavy).(Yuldashev, 2007)

We need to protect our literary language from agonyms, to create the necessary attention to its enrichment. As in all periods, the pure development of the language depends to some extent on the services of the representatives of the industry such as journalists, writers, teachers and linguists. In Linguistics, "Conscious Interference in the Life of Language," "Conscious Management of Language," "Regulation of Language," "Language normalization ",“ Defining language norms ”,“ Language grinding ”,“ Improving language norms "," Language processing" which represents the theoretical and practical work related to the intervention of writers and linguists in the development and richness of language " (Begmatov, 1999). All of the above concepts imply that linguists, scholars are involved in the purity of language, its further refinement, the prevention of distortions in nomenclature, and the correct use of a word or term.

The phenomenon of distortion in the Uzbek language is also observed in the field of toponymy. Names in this field are formed based on the history, geography, ethnography and language materials of the country. The main function of place names is to identify a certain area, to indicate its location relative to another. Unfortunately, there are a lot of meaningless names that do not belong to the Uzbek nation, for example: Chirkay, Chozma, Kekirtak, etc. Or there is a theory that these 
names are mispronounced by Russianspeaking people. The Uzbek spelling of city, village, street names, and geographical names in general did not interest anyone at that time and not to mention the Russian spelling of the names. Arkhangelskiy who was a Russian scholar writes of the process: "The Russianlanguage form of the Central Asian geographical nomenclature during the Tsarist period is very different from the form of the names of geographical objects accepted by the local population" (Arkhangelskiy, 1934). Thus, the Russian spelling of geographical names differed significantly from the pronunciation of both national and Uzbek spellings. One of the main reasons is the toponymic maps, geographical maps, along with other records in them information such as names, list of settlements were usually filled out in Russian by people who did not speak Uzbek well. It was later translated into Uzbek when needed. As a result, many mistakes were made without taking into account local conditions.

\section{RESULTS AND DISCUSSIONS}

In Utkir Hoshimov's story "Itbozga ehtirom" (Respect for the Dog-fancier), Dukhnovsky means "what nicknames should be given to dogs?" In a large article entitled "Do not give a human name to the dog", he lists the nicknames given to dogs: Askar, Botir, Komila, etc ... "(Hoshimov, 2013). The more annoying the Uzbek names given to the dog, the more influential the inaccuracy in naming places. For example, some village and guzar names in Uchkuprik district have unusual meanings. M: The name of Momachol qishloq (Momachol village) or Daydi qishloq (Daydi village) is also somehow uncomfortable to hear. We can say that it has passed to the level of the norm by word of mouth among the people as used for many years. However, naming any name in accordance with Uzbek national traditions creates some agony in the language.

Toponyms are a valuable historical and linguistic source. They are narrators of the people's past and history. In addition to providing information about ethnic processes, it is also a unique lexical layer. As the place names retain the source and feature of a forgotten people. Today, great importance is attached to the toponymic policy pursued in our country. There was a need to adapt place names to national traditions. Place names such as "Bostonsaray", "Nurafshon", "Solim", "Sharq", “Buyuk ipak yoli”, "Gulobod", “Bogbonlar”, "Ziyolilar”, "Qadriyat” have a strong place in our language.

The names in the advertisements on the roofs of buildings in the streets of our country are completely contrary to the laws of the Uzbek language. Regardless where you are in the streets of the capital or in any regional center, you feel as if you have fallen abroad. Most of the advertisements on the roofs of buildings are written in foreign languages. Restaurants "Salsal”, "Simsim", “Florence", "Sushi bar Yaposha”, “Lopera”, “El Gaucho”, “Roma pizza”, “La miranda”, “Rojo ojo”, “Luk” , "Dolche Fredo", "Burger House", "Coffee Like", "Golden Fork", "Al Dolphin", "Marrakesh", "Somsa House", "La Cuchina", "Chemodan.uz" cases remain the object of ecolinguistic science. Today, the independence of our country has opened a wide way for all spheres. We have entered into direct contact with the world; the gates of the country have been opened to the 
world. What make us feel pathetic is that the introduction of new words into our language has accelerated.

The fact that words related to the profession are expressed almost as if they were in Russian or English indicates that the importance of the Uzbek language is declining. The butcher calls the thigh meat lyashka, chops-dandana, tender loin - koreyka, as if the butcher job had never been here before, as the term came from the Russian language recently.

The master of the period, like a pure Uzbek word, uses plaster as shtukaturka, shayin as uroven, and chaspak as plinth, which means that almost all construction terms are becoming more and more pronounced in Russian names.

The shoes master calls the skin "koja," the salesman calls pants- " short" and short pants"shorts"; the words are being used such as garden- "park", the boots- "sapog", the bridge- "most", the barn- "hranilishcha", the spoon- "lojka", father- "pahan", mother"mahan" and etc.

In recent years, development has accelerated in all areas of our country. It is no secret that the world community is amazed by the creative work taking place in our country. Nevertheless, it is becoming a habit to call buildings and enterprises under construction in inappropriate, incomprehensible, in a word, agonyms. For instance: Place names such as "Miss Kamila", "Golden Chicken", "Petrol", "Elegant", "Ferganskiy Dvorik", "Kvik", "Bagozza", "Boyarin", the firms named such as "Indaba”, "Nek star", "Rayyona Ishonchservis X.K”, “Alyor teks”, “Rash milk”, “Dinur- lend”, "Chinkamol”, "Asklepiy”. "So, what we can say to names which have no meaning for the Uzbek language and for Uzbek people?!" Any linguist is unable to explain the meaning of such names as KKBFMNKM regional department, "Asaka MAK LLC", "Samosherteks", "SulSherJahon" and etc.

\section{CONCLUSION}

In conclusion, such agonyms in nomenclature mean nothing more than ideological oppression underlying a simple name. When the aspirations of the world's sovereign states to subjugate other peoples by influencing the unarmed consciousness in the hope of redistributing the world are growing, we are giving our company, farm, hotel the name without thinking well. What do we say to the next generation tomorrow?! It is not a sign of the poverty of our language, however, the negligence of officials and language illiteracy. If we manage to eliminate the differences in the leadership of the relevant organizations, we will be able to make the Uzbek language even clearer and more perfect.

\section{REFERENCES}

1. 1. Alisher Navoi...Muhokamat ul-lug'atayn. Translation by Vahob Rakhmonov. Tashkent: Tafakkur

2. N.Mahmudov. Journal of Word Art.2018.№1

3. Marufjon Yuldashev. Fundamentals of literary text and its lingvopoetic analysis. Tashkent: Fan. 2007.

4. E.Begmatov, A.Mamatov. Literary norm theory. (Laws of formation and existence of the literary norm. Part III. - Tashkent: 1999. 
5. Arkhangelsky N.P. Central Asian issues of geographic atamology and transcription. Tashkent 1934, p.14

6. Hoshimov O. Inscriptions in the frame of the notebook. - Tashkent: Sharq, 2013.

7. A.Sobirov. Current issues of linguistics: VI. - Tashkent: Akademnashr, 2012. 